\title{
Forest inventory-based assessments of the invasion risk of Pseudotsuga menziesii (Mirb.) Franco and Quercus rubra L. in Germany
}

\author{
A. Bindewald ${ }^{1,2} \circledast$. S. Miocic ${ }^{1} \cdot$ A. Wedler ${ }^{1} \cdot$ J. Bauhus $^{2}$
}

Received: 9 December 2020 / Revised: 17 February 2021 / Accepted: 2 March 2021 / Published online: 26 March 2021

(c) The Author(s) 2021

\begin{abstract}
In Europe, some non-native tree species (NNT) are classified as invasive because they have spread into semi-natural habitats. Yet, available risk assessment protocols are often based on a few limited case studies with unknown representativeness and uncertain data quality. This is particularly problematic when negative impacts of NNT are confined to particular ecosystems or processes, whilst providing valuable ecosystem services elsewhere. Here, we filled this knowledge gap and assessed invasion risks of two controversially discussed NNT in Germany (Quercus rubra L., Pseudotsuga menziesii (Mirb.) Franco) for broad forest types using large scale inventory data. For this purpose, establishment success of natural regeneration was quantified in terms of cover and height classes. The current extent of spread into protected forest habitats was investigated in south-west Germany using regional data. Establishment was most successful at sites where the NNT are abundant in the canopy and where sufficient light is available in the understory. Natural regeneration of both NNT was observed in $0.3 \%$ of the total area of protected habitats. In forest habitats with sufficient light in the understory and competitively inferior tree species, there is a risk that Douglas fir and red oak cause changes in species composition in the absence of management interventions. The installation of buffer zones and regular removal of unwanted regeneration could minimize such risks for protected areas. Our study showed that forest inventories can provide valuable data for comparing the establishment risk of NNT amongst ecosystem types, regions or jurisdictions. This information can be improved by recording the abundance and developmental stage of widespread NNT, particularly in semi-natural ecosystems.
\end{abstract}

Keywords Risk assessment $\cdot$ Invasive tree $\cdot$ National forest inventory $\cdot$ Natural regeneration $\cdot$ Forest management

\section{Introduction}

Humans have historically influenced forests in many different ways. One of these influences is the change in tree species composition through introduction and promotion of non-native tree species, i.e. with a natural range outside Europe (hereinafter NNT). Primarily, NNT have been used for afforestation of degraded sites and for production of

Communicated by Thomas Knoke.

A. Bindewald

anja.bindewald@forst.bwl.de

1 Department of Forest Conservation, Forest Research Institute of Baden-Württemberg (FVA), 79100 Freiburg, Germany

2 Chair of Silviculture, University of Freiburg, 79085 Freiburg, Germany timber (Brus et al. 2019). In recent years, some drought-tolerant NNT are being increasingly discussed as alternatives for native species in the face of climate change (Bauhus et al. 2013; Bolte et al. 2009; De Avila and Albrecht 2018). At the same time, human impact on NNT distribution can enhance their invasion success (here spread and establishment) due to increased propagule pressure, i.e. the number of individuals introduced and the frequency of introduction events (Dodet and Collet 2012; Lockwood et al. 2005; Pyšek 2016). There are several studies in Europe reporting NNT spreading from managed stands into adjoining areas where they eventually establish and pose risks to biodiversity (e.g. Campagnaro et al. 2018; Wagner et al. 2017). Particularly within sensitive ecosystems such as the European Union habitat types, NNT may have a substantial detrimental impact when they outcompete native species or alter the structure and function of ecosystems (Campagnaro et al. 2018; Castro-Díez et al. 2019). One key challenge in this context is to benefit from 
the ecosystem services provided by NNT, whilst minimising their detrimental impacts (Brundu and Richardson 2016), for example, by identifying ecosystem types or demarcated areas where they can be cultivated with a low risk of invasion (Rouget et al. 2002). Invasion risks of NNT strongly depend on the type of ecosystem (Pyšek et al. 2012; Sapsford et al. 2020; Vor et al. 2015) emphasizing the importance for analysing the spatial extent for potential or existing invasive NNT (Hawkins et al. 2015; Rouget et al. 2002).

Diverse methods to assess the invasion risks of non-native plant species have been developed and they are key components to inform management and policy (Hulme et al. 2013; Roy et al. 2018). Both risk and forest management of NNT require site-specific approaches (Sádlo et al. 2017). Thus, a stratified assessment of invasion risks posed by NNT which distinguishes amongst different ecosystem types is of critical importance. However, there are still deficits in addressing the context dependency in the assessment methods i.e. locally differing invasiveness potentials (Bartz and Kowarik 2019). Available risk assessment protocols of NNT in Central Europe rarely consider the extent of the area impacted or invaded and evaluations are often based on a few, limited case studies with unknown representativeness (Bindewald et al. 2019, 2020). As a consequence, locally observations of negative impacts are generalised and extrapolated to larger spatial scales by providing one single risk classification (Bartz and Kowarik 2019; Bindewald et al. 2020). These uncertainties in methods can hamper responsible NNT management, particularly when a species has negative impacts in one type of ecosystem, whilst providing valuable ecosystem services elsewhere (e.g. Robinia pseudoacacia L.) (Vítková et al. 2017). Additionally, if data are poor, invasiveness is frequently assumed following the precautionary principle, but without clear scientific evidence (Aven 2011; Davis et al. 2011; Strubbe et al. 2011). Such approaches are not transparent and reliable (Bartz and Kowarik 2019), and they can exacerbate conflicts of interest in the use and management of NNT (e.g. Ammer et al. 2014; Dickie et al. 2014; van Wilgen and Richardson 2014; Vítková et al. 2017).

It is difficult to assess the invasion risks of NNT comprehensively because there is no consistent and systematic monitoring of biological invasions for the total area of any given region (Latombe et al. 2016). Highly relevant for monitoring are recent studies describing the possibilities of using large-scale forest data to provide comprehensive insights into forest plant invasions (e.g. Oswalt et al. 2015; Wagner et al. 2017). Forests in European countries are regularly monitored at the national level (Tomppo et al. 2010), however, the data have rarely been used for assessing invasion risks of NNT (e.g. Verheyen et al. 2007; Wagner et al. 2017). Traditionally, National Forest Inventories (hereinafter NFI) aim to provide regular updates on the state of forest resources, including timber volumes and tree species' composition. More recently, NFIs and the analyses of their data have been expanded to address questions of biodiversity conservation and thus replace expert opinions and qualitative assessments (e.g. Kovac et al. 2019; Storch et al. 2018). Systematically collected forest inventory data provide consistent data sets that appear useful for analysing spatial and temporal patterns of tree recruitment across different ecosystems. Therefore, we propose that risk assessment approaches of presumably invasive and widely cultivated NNT can also benefit from such databases.

Here, we used forest inventory data to support the risk assessments of the two NNT Douglas fir (Pseudotsuga menziesii (Mirb.) Franco) and red oak (Quercus rubra L.) which have been introduced from North America to Europe in the nineteenth and seventeenth century, respectively (Krumm and Vítková 2016). These two NNT are controversial in Germany since their invasion potentials are perceived differently by nature conservation and forest scientists (Nehring et al. 2013; Vor et al. 2015, 2016). The current state of knowledge is however mainly based on a few case studies with different levels of evidence. Information about the site-specific establishment potential and the ecosystem types most sensitive to invasion remains poor for several regions throughout Central Europe (Schmid et al. 2014; Wohlgemuth et al. 2019). The aim of the study was to explore the potential of large-scale forest inventories to strengthen the evidence-base (Strubbe et al. 2019) for risk assessments of widespread NNT. We present this approach by assessing natural regeneration as a measure of establishment success of Douglas fir and red oak in different forest types throughout Germany. Based on previous studies we hypothesized that:

1. The non-native tree species Pseudotsuga menziesii and Quercus rubra have a low spread potential and thus rarely establish on sites where they are not cultivated.

2. The availability of light in the understorey limits the establishment of both tree species.

To test these hypotheses and to assess invasion risks of the two non-native tree species for a range of sites, our specific objectives were to:

1. Compare natural regeneration established in different forest types and identify those types that facilitate establishment,

2. Analyse the temporal development of regeneration over one 10-year inventory period (2002-2012) in order to obtain information on establishment success or failure,

3. Identify invaded, protected forest habitats and

4. Prioritize ecosystem types that are sensitive to invasion and suggest management measures to mitigate any negative effects. 
The first two questions are addressed through analyses of the German national forest inventory data, the latter two with data from Selective Forest Habitat Mapping in southwest Germany.

\section{Methods}

\section{Study area and inventory data}

The analysis of NFI data focussed on the most recent inventory period from 2002 and 2012 for Germany (hereinafter $\mathrm{NFI}_{2002}$ and $\mathrm{NFI}_{2012}$ ) (Table 1). NFI data of Germany is publicly available (BMEL 2012). The large-scale inventory is carried out every 10 years and provides data on the state and productivity of forests (see Polley et al. 2010 for complete sampling design). Although the sampled area is relatively small, it is considered a representative section of the forests to derive information for the entire forest area. The inventory design is based on a systematic grid-based sampling with varying densities of $2 \times 2 \mathrm{~km}, 2.83 \times 2 \mathrm{~km}$, or $4 \times 4 \mathrm{~km}$ across individual federal states in Germany. Data is monitored in four permanent inventory plots for each grid intersection point (if located in forest areas) at a distance of $150 \mathrm{~m}$ to each other (Fig. 1). At each inventory plot, data are recorded at individual circular plots or via the angle count (relascope) method (Holgate 1967). Data on the regeneration cohort and young stand between $20 \mathrm{~cm}$ and $4 \mathrm{~m}$ in height are collected in a circular plot with $10 \mathrm{~m}$ radius $(0.03 \mathrm{ha})$ in which the percentage cover of seedlings and saplings is recorded in steps of $10 \%$. Artificial and natural regeneration are differentiated at each inventory plot. The number of individual seedlings is counted in height classes in a circular plot with a radius of $1 \mathrm{~m}$ for the trees between 20 and $50 \mathrm{~cm}$ in height and with a radius of $2 \mathrm{~m}$ for saplings and small trees with a height $>50 \mathrm{~cm}$ and a diameter $<7 \mathrm{~cm}$ at breast height (DBH at $1.3 \mathrm{~m}$ ). Variables such as species, DBH, basal area and vertical stratification (understory, main stand, overstory) are assessed for all trees with a $\mathrm{DBH} \geq 7 \mathrm{~cm}$ by using an angle count sampling factor of 4 . The main stand is defined as the highest tree layer whose cover made up $\geq 50 \%$ of the canopy. Tree species occurring below or above the main canopy are classified as understory or overstory. The number of individual trees of each species and forest layer are recorded for all trees with a height $>4 \mathrm{~m}$ using angle count sampling factor 1 or 2. Additional information characterizing terrain features and the potential natural forest community which would develop under current site conditions are assessed in a circular plot with a radius of $25 \mathrm{~m}(0.196 \mathrm{ha})$. The coordinates of the inventory plots are not publicly available.

Since establishment of non-native tree species is of particular concern for protected ecosystems, we focussed another part of the analysis on these. Since these protected areas cover only a small fraction of the total forest area, they are not well represented in the NFI, which is therefore not suitable for that analysis. Yet, there is neither a consistent method for monitoring the protected forest habitats across the 16 different states of Germany nor are data entirely digitalised and/or available for each region (Materne and Bindewald, unpubl.). For that reason, we have used the data collected in the so-called Selective Forest Habitat Mapping (hereinafter $S F H M$ ) for the state of Baden-Württemberg in south-west Germany (Table 1), see for example Bindewald and Michiels (2018). In this region habitat monitoring is managed by the Forest Research Institute (FVA). For this study we used the most recent inventory data accessed in 2019. Since 1989, the SFHM has been an important tool for the preservation and management of forest areas and species of high conservation value, including transient areas to open landscapes. Rare and valuable forest habitats protected by nature conservation laws ( $\$ 33$ Nature Conservation Act BW, §30a Forest Law BW, §30 German Federal Nature Conservation Act, EU Habitats Directive) are recorded and monitored every 10 years with yearly updates for different regions. Habitats are assigned to one of 12 habitat types (Table S6). For example, 33\% of the entire sampled area (i.e. 26,617 ha) is assigned to the habitat type rare near-natural forest types. The current status of each habitat is assessed based on information about occurrence of certain character species, habitat size, location, and current threats (see Kerner and Geisel 2017 for methodology and habitat descriptions). Monitoring of the stands includes the compilation of (incomplete) plant species lists including NNT. Natural regeneration of NNT is recorded as a risk, if surveyors consider establishment of the species a (potential) threat to the habitat, otherwise occurrence is recorded in the plant species list. In most cases,
Table 1 Overview of the databases used for the risk assessment

\begin{tabular}{|c|c|c|c|}
\hline Inventory & $\mathrm{NFI}_{2002}$ & $\mathrm{NFI}_{2012}$ & SFHM (accessed in 2019) \\
\hline Reference area & Germany & Germany & State of Baden-Württemberg \\
\hline Sampling area & All types of forests & All types of forests & $\begin{array}{l}\text { Forest habitats of high con- } \\
\text { servation value }\end{array}$ \\
\hline Total area (ha) & $10,320,601$ & $11,419,124$ & 82,137 \\
\hline $\begin{array}{l}\text { Total number of inventory } \\
\text { plots (NFI) / habitats } \\
\text { (SFHM) }\end{array}$ & 45,085 & 49,072 & 63,936 \\
\hline
\end{tabular}




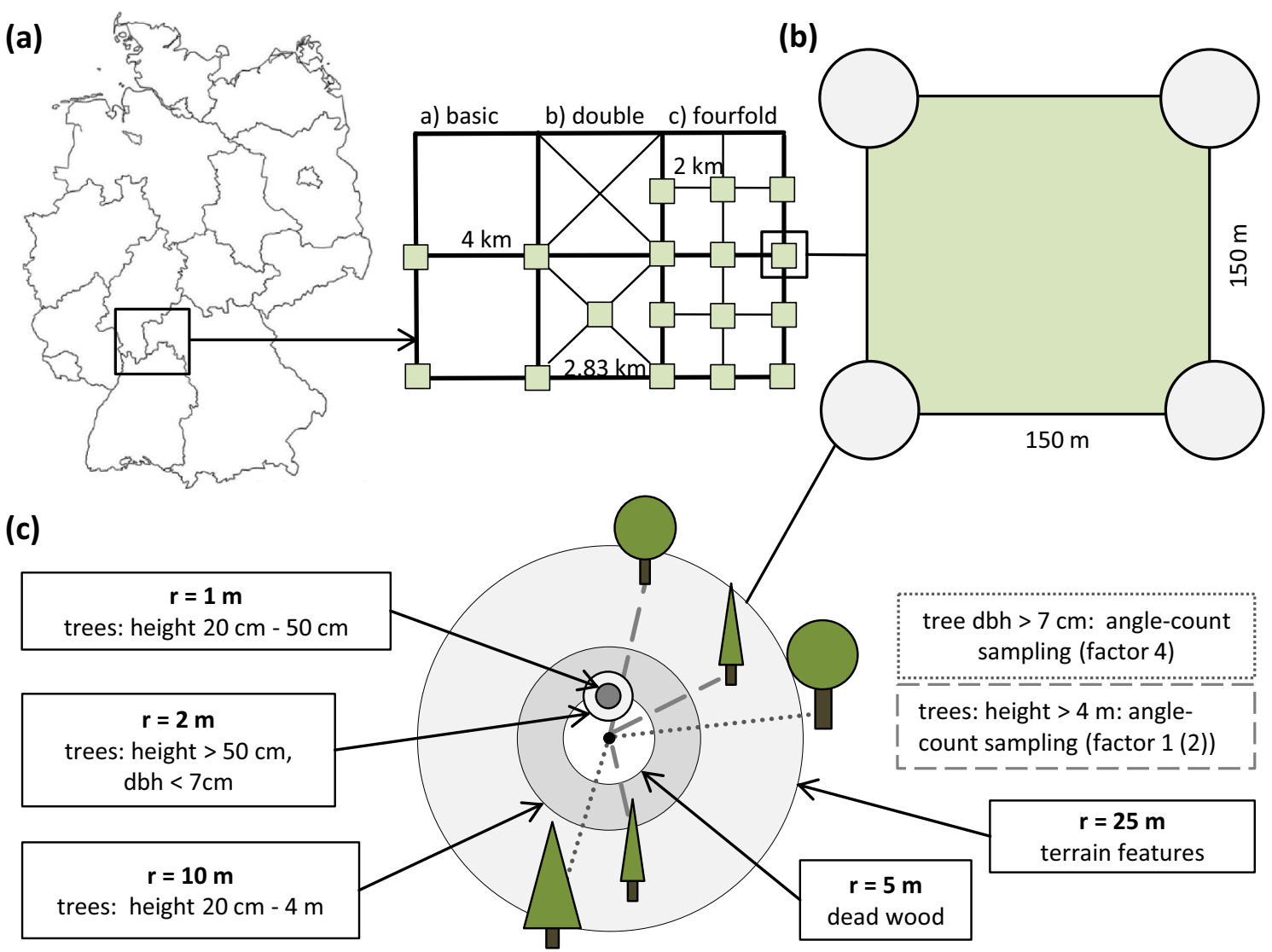

Fig. 1 Sampling plot design of the German National Forest Inventory (adapted from Polley et al. 2010): a the density of the systematic sample grid varies across the German federal states, $\mathbf{b}$ four permanent inventory plots for each grid intersection point, $\mathbf{c}$ data recorded for each inventory plot

covering $\geq 30 \%$ of the total basal area were defined as the main tree species. In addition, only those species which occurred as a main tree with a relative frequency of $\geq 10 \%$ across all inventory plots were classified as a specific stand type. Plots that could not be characterised in this way were summarized under other coniferous tree species (i.e. Larix kaempferi, Pinus strobus, Picea sitchensis, Abies alba, other pines, other firs), and other broadleaved tree species (i.e. Acer pseudoplatanus, Betula pendula, Castanea sativa, Carpinus betulus, Fraxinus excelsior, Populus balsamifera, Populus tremula, Prunus avium Robina pseudoacacia, Sorbus aria, Tilia spec.), depending on the tree species dominating the canopy in the main stand. Quercus robur and $Q$. petraea were pooled to form the stand type European oaks.

Inventory plots were further classified based on the presence or absence of Douglas fir or red oak in the canopy as an indication of their potential to spread. Plots where Douglas fir or red oak covered $\geq 30 \%$ of the total basal area were assigned NNT main tree. Depending on whether Douglas fir or red oak occurred in the canopy, inventory plots were assigned to NNT present or NNT absent, based 
on data collected by angle count sampling factor 4 and 2(1)). Inventory plots where the NNT occurred as a canopy tree in 2002 were removed from the dataset of the year 2012 since recorded seedlings or saplings may have originated from the previous inventory period ( $n=11$ for Douglas fir, $n=3$ for red oak).

To assess the influence of light availability on cover and height of natural regeneration of NNT, plots were classified in terms of expected light conditions below the canopy. Light conditions were not directly measured within the NFI and there is no quantitative information available on canopy cover. Hence, we estimated light levels in the understorey in three categories by using information on tree species composition. Since variation in light availability at the forest floor is strongly influenced by the structure and composition of the over- and understory (Montgomery 2004) we took into account both recorded tree species in the main stand and in the understory. Since shade-tolerant tree species can endure more self-shading within crowns, they typically have longer green crowns and higher specific leaf areas (Givnish 1988; Stijntje Janse-Ten Klooster et al. 2007) and hence also cast more shade. Therefore, each tree recorded in the main stand or understory was assigned to a light category according to species-specific shade tolerance values (Niinemets and Valladares 2006) and typical leaf area indexes (e.g. Bequet et al. 2012) (Table 2). Plots with shade-tolerant tree species that develop large and dense crowns like beech (Fagus sylvatica L.) or silver fir (Abies alba Mill.) were classified as sites

Table 2 List of tree species in the main stand and understory according to expected light availability below the canopy in different forest stands

\begin{tabular}{lll}
\hline Low light availability & $\begin{array}{l}\text { Medium light avail- } \\
\text { ability }\end{array}$ & High light availability \\
\hline Abies others & Acer platanoides & Alnus glutinosa \\
Abies alba & Acer campestre & Betula pendula \\
Abies grandis & Acer pseudoplatanus & Larix decidua \\
Carpinus betulus & Castanea sativa & Larix kaempferi \\
Fagus sylvatica & Fraxinus exelsior & Pinus nigra \\
Picea abies & Prunus avium & Pinus others \\
Picea sitchensis & Prunus serotina & Pinus strobus \\
Picea others & Pseudotsuga men- & Pinus sylvestris \\
& ziesii & \\
Tilia spec & Quercus petraea & Populus alba \\
& Quercus robur & Populus nigra \\
& Quercus rubra & Populus tremula \\
& & Populus trichocarpax \\
& & maximoviczii \\
& & Robinia pseudoacacia \\
& & Salix spec \\
& & Sorbus aria \\
& & Sorbus aucuparia \\
\hline
\end{tabular}

with low light availability. Inventory plots characterized by light demanding and fast growing pioneer species like silver birch (Betula pendula Roth), or Scots pine (Pinus sylvestris L.), were classified as high light availability. Inventory plots composed of moderately shade-tolerant tree species with medium leaf area indexes, like the European oaks, were classified as medium light availability. For all inventory plots where tree species were recorded in the main stand as well as in the understory ( $n=123$ for Douglas fir, $n=64$ for red oak), more weight was given to the understory if there was a difference in only one light category (Table 3).

Temporal development of regeneration between 2002 and 2012 was analysed by comparing the proportions of individual tree species recorded in height classes. Tree numbers were counted in several height classes within the NFI. We calculated tree numbers per square metre and summarized the data as follows: height $20-50 \mathrm{~cm}(h c 1), 50.1-130 \mathrm{~cm}$ ( hc2), $>130 \mathrm{~cm} \& \mathrm{DBH}<7 \mathrm{~cm}(h c 3)$. Additionally, we compared the counts of all inventory plots according to the three height classes $\left(\mathrm{NFI}_{2012}\right.$ and $\left.\mathrm{NFI}_{2002}\right)$.

\section{SFHM}

Database entries for each individual habitat with occurrences of Douglas fir or red oak were analysed based on habitat descriptions, surveyor comments and management proposals. Habitats where natural regeneration has been clearly documented and/or habitats which have been considered at risk because of the natural regeneration of the two NNT were included in our dataset as invaded habitats. We did not distinguish between habitats at risk and invaded since there was no systematic and transparent procedure to classify such a risk (Table 4).

Table 3 'If' conditions used to classify inventory plots according to expected light availability below the canopy

\begin{tabular}{lll}
\hline $\begin{array}{l}\text { If 'light availability' } \\
\text { main stand }\end{array}$ & $\begin{array}{l}\text { and 'light availability' } \\
\text { understory }\end{array}$ & $\begin{array}{l}\text { then 'light avail- } \\
\text { ability' inventory } \\
\text { plot }\end{array}$ \\
\hline Low & Low & Low \\
Medium & Low & Low \\
High & Low & Medium \\
Low & Medium & Medium \\
Medium & Medium & Medium \\
High & Medium & Medium \\
Low & High & Medium \\
Medium & High & High \\
High & High & High \\
\hline
\end{tabular}


Table 4 Overview of data derived from the German $\mathrm{NFI}_{2002}$ and $\mathrm{NFI}_{2012}$. Natural regeneration is defined as seedlings $>20 \mathrm{~cm}$ and $<4 \mathrm{~m}$ in height, canopy trees are defined as trees $>4 \mathrm{~m}$ in height, or $>7 \mathrm{~cm} \mathrm{DBH}$ (angle count sampling method)

\begin{tabular}{|c|c|c|c|c|}
\hline \multirow{2}{*}{$\begin{array}{l}\text { Non-native tree species (NNT) } \\
\text { Year of national forest inventory }\end{array}$} & \multicolumn{2}{|l|}{ Douglas fir } & \multicolumn{2}{|l|}{ Red oak } \\
\hline & 2002 & 2012 & 2002 & 2012 \\
\hline $\begin{array}{l}\text { Total representative stand area (ha) where the NNT (height }>20 \mathrm{~cm} \text { ) was growing }{ }^{\mathrm{a}} \\
\text { (percent of total forest area in Germany with the NNT) }\end{array}$ & $179,607(1.7)$ & $217,604(1.9)$ & $43,960(0.4)$ & $54,533(0.5)$ \\
\hline Total number of inventory plots where the NNT occurred as a canopy tree & 3094 & 3730 & 749 & 1012 \\
\hline Total number of inventory plots where the NNT was naturally regenerating & 438 & 818 & 157 & 355 \\
\hline Total number of inventory plots where height classes of seedlings were recorded & 123 & 326 & 67 & 182 \\
\hline $\begin{array}{l}\text { Percent of inventory plots where the NNT was naturally regenerating but did not } \\
\text { occur as a canopy tree }\end{array}$ & 49 & 43 & 38 & 55 \\
\hline $\begin{array}{l}\text { Percent of inventory plots where the NNT occurred as a canopy tree but was not } \\
\text { naturally regenerating }\end{array}$ & 93 & 88 & 87 & 84 \\
\hline
\end{tabular}

ahttps://bwi.info; 77Z1JI_L357oa_2002; 77Z1JI_L657of_2012_bi_Ba

\section{Statistical analysis}

Normal distribution of data was tested using the Shapiro-Wilk test. Homogeneity of variances for group factors was tested using Levene's-Test. Not all data within the groups of stand types, NNT presencelabsence/dominance, and light availability, met the assumptions for parametric tests (i.e. homoscedasticity and normal distribution). To compare regeneration cover for different groups, we used Welch's correction of analysis of variance (ANOVA) since this method is suitable for unbalanced data and handles variance heterogeneity well (Liu 2015). Subsequently, the nonparametric Games-Howell post-hoc test was used to assess differences in all pairs of groups. Mean cover of Douglas fir and red oak natural regeneration in 2002 and 2012 were compared using Welch's unequal variances two sample t-test. All statistical analyses were conducted using the $R$ software package (versions 1.1.423).

\section{Results}

\section{Main results}

In 2012, Douglas fir and red oak covered $1.9 \%$ and $0.5 \%$ of the total forest area in Germany, respectively (BMEL 2018) (Table 5). Compared to 2002, the forest area of Douglas fir increased by $17.5 \%$ and that of red oak by $19.9 \%$. The area covered by Douglas fir peaked in the age class 21-40 years in 2002 and 41-60 years in 2012. Most forest area covered by read oak was in the age class 41-60 years in both inventory years (Fig. S3 in the electronic Supplementary material 2).

In 2012, natural regeneration of Douglas fir was identified on 818 and that of red oak on 355 inventory plots out of a total number of 49,072 NFI plots. The plots carrying Douglas fir regeneration were mainly situated on slopes and the main stand at these plots was typically composed of spruce (Picea abies (L.) H. Karst.), Douglas fir, and beech (Fagus sylvatica L.). In the regeneration cohort, Douglas fir was frequently accompanied by beech, spruce, and silver fir (Fig. S1, S2). The majority of plots were located in the areas where beech would dominate potentially natural forest communities such as the Luzulo-Fagetum, which occurs mostly on acidic and nutrient-poor soils (Schmidt 1999) (Table S1). Natural regeneration of red oak occurred primarily in the plains, where the main stands were typically composed of pine, red oak and silver birch. Frequent companion tree species in the regeneration cohort were rowan (Sorbus aucuparia L.), beech, and sessile oak (Fig. $\mathrm{S} 1, \mathrm{~S} 2)$. Inventory plots were located in different types of potentially natural vegetation such as the Luzulo-Fagetum and Querco-Tilietum. The latter occurs on moderately acidic and nutrient-poor soils (Schmidt 1999) (Table S1).

\section{Natural regeneration in different forest types}

Regeneration cover of Douglas fir was significantly higher in the Douglas fir stand type than in other stand types $(p<0.001)$. Similarly, regeneration cover of red oak was significantly higher in the red oak stand type than in other stand types $(p<0.001)$ except for other deciduous trees and silver birch (Fig. 2a, Table S2).

The highest number of inventory plots with natural regeneration was found in sites where both NNT were absent in the canopy. However, participation of the two NNT in the main canopy had a significant influence on the mean cover of Douglas fir and red oak in the regeneration layer. Mean regeneration cover of the two species was highest at sites, where the two species dominated the canopy, and lowest at sites where both NNT were absent $(p<0.001)$ (Fig. 2 b, 
Table S2). Yet, presence of NNT as a canopy tree at the level of all inventory plots was a poor predictor of regeneration. In $88 \%$ (Douglas fir) and $84 \%$ (red oak) of plots with these species in the main canopy, they had not regenerated (Table 5). However, information on tree age to indicate whether trees were actually sexually mature was not available to further qualify this information. Yet, it is obvious from the age class distribution of the two species in the NFI (Fig. S3) that ca. $50 \%$ (in Douglas fir) and more (in red oak) of the stands are older than 40 years and therefore should be producing seeds. The total number of seedlings per square metre was the highest for all height classes of seedlings and saplings in inventory plots where the NNT was also the main canopy tree species (Fig. 2b, Table S2).

Regeneration cover of both NNT increased from sites with low to high light availability (Douglas fir: $p<0.05$, red oak: $p<0.001$ ) (Fig. 3, Table S2). Total number of seedlings across different height classes was higher at the sites with medium and high light availability compared to the sites with low light availability. The number of red oak seedlings in hc1 was conspicuously higher at sites with high light availability when compared to the other sites (Fig. 3).

\section{Temporal development between 2002 and 2012}

The number of inventory plots with Douglas fir and red oak natural regeneration approximately doubled between 2002 and 2012 (Table 5). There was a significant increase in the mean regeneration cover of Douglas fir between 2002 (26\%) and $2012(31 \%)(p<0.001)$ but no significant difference in the cover of red oak. Temporal changes in the proportion of seedlings in the different height classes showed similar patterns for both NNT between $\mathrm{NFI}_{2002}$ and $\mathrm{NFI}_{2012}$. The proportion of Douglas fir seedlings in the lowest height class 1 increased by $41 \%$ and that of red oak by $10 \%$, whilst proportions of both NNT in height class 2 decreased by about $10 \%$. The proportion in height class 3 decreased by $29 \%$ for Douglas fir and increased by $2 \%$ for red oak (Fig. $4 a$ ). The number of inventory plots with seedlings recorded in the different height classes increased across all height classes for both species, particularly in height class 1 (Fig. 4b).

\section{Natural regeneration in forest habitats of high conservation value}

South-west Germany is divided into seven natural regions, which are characterized by distinct geological substrates and climatic conditions (Michiels 2014). Results from the SFHM show, that natural regeneration of both NNT occurred in protected forest habitat reserves across all natural regions except the Swabian Alb, where no evidence of regenerating was found (Fig. 5). Most observations of red oak were made in the Rhine Valley and of Douglas fir in the Black Forest regions. Natural regeneration of Douglas fir was monitored in 219 habitat reserves located in 11 different habitat types, whilst that of red oak in 51 habitat reserves located in 9 different habitat types (Table S3). These habitat reserves cover a total of 245 ha in the case of Douglas fir and 275 ha in the case of red oak, i.e. in each case about $0.3 \%$ of the total habitat area in south-west Germany. Within these habitat types, the largest area where natural regeneration of Douglas fir (145 ha) and red oak (194 ha) was recorded was in the type rare near-natural forests. Within this habitat type, natural regeneration of Douglas fir was recorded in ten different forest types of which seven are assigned to European Union habitat types (see Table 5 for an overview). The largest habitat area (101 ha) and share (18\%) where natural regeneration of Douglas fir was monitored was located in the sessile oak forest community (Luzulo-Quercetum) on dry sites with acidic soils. Red oak regeneration was recorded in nine different forest types of which seven are assigned to European Union habitat types (see Table 5 for an overview). The largest habitat area where red oak natural regeneration has been reported (i.e. 127 ha) was situated in the oak-hornbeam (Carpinus betulus L.) forest community (habitat type 9160) on the moderately fresh to periodically wet sites. The greatest share of reserves with red oak regeneration (11\%) occurred in the sessile oak-European beech community (habitat type 9190) which is located on moderately dry sites with acidic soils.

\section{Discussion}

\section{The influence of site and stand condition on establishment}

We found significant differences in seedling abundance of Douglas fir and red oak between forest types in Germany. Overall, there was little regeneration of both NNT with the exception of stands where they formed the dominant tree species in the canopy and with sufficient light in the understory.

Seed dispersal is a key factor allowing NNT to become invasive (Chytrý et al. 2008; Richardson et al. 2000). However, establishment success depends on additional factors. Seedling density and height are very important to overcome competition and for forming a sustainable population (Lockwood et al. 2005; Vanhellemont et al. 2009). Thus, regeneration success of a species can be expressed by both seedling abundance (here cover and number of seedlings), and the quantity of trees establishing as secure regeneration, that are taller than $130 \mathrm{~cm}$ (here hc3) (hereinafter saplings). Above this height, terminal buds of saplings are out of the reach 
Table 5 Natural regeneration of Douglas fir and red oak in protected forest habitats in the State of Baden-Württemberg (SFHM 2019). Code $=$ European habitat code according to the Habitat Directive 2019; nat.reg. $=$ natural regeneration

Code Forest types

\begin{tabular}{lll}
$\begin{array}{l}\text { Entire } \\
\text { habitat area } \\
\text { (ha) }\end{array}$ & $\begin{array}{l}\text { Area with } \\
\text { nat. reg. } \\
\text { (ha) })^{\mathrm{a}}\end{array}$ & $\begin{array}{l}\text { Share of } \\
\text { habitat area } \\
(\%)\end{array}$ \\
\hline
\end{tabular}

Douglas fir

Oak forest, Luzula luzuloides - Quercus petreae, moderate dry sites, base poor and acidic soils, colline to montane altitudes

9180 Block forest, Deschampsia flexuosa-Acer pseudoplatanus, on base poor soils, colline to montane altitudes

9110 Beech forest, Vaccinium myrtillus — Fagus sylvatica, partial with Abies alba, nutrient-deficient, moderate dry and acidic soils, colline to montane altitudes

Ravine and block forest, Betula pubescens—Sorbus aucuparia, on base-poor, moderate fresh and moderate dry sites, colline to montane altitudes

9180 Block forest, Tilia spec.-Quercus petreae, slope and block forest on base poor soils, colline to montane altitudes

9110 Beech forest, Luzula luzuloides — Fagus sylvatica partial with Abies alba, nutrient poor and moderate dry sites, acidic soils with mould, colline to montane altitudes

Slope forest, Lithospermum purpurocaeruleum-Quercus spec., forests in the surrounding of rocks, very dry sites, colline to montane altitudes

9180 Block forest, Acer-Fraxinus excelsior, with either high air humidity or wet soils, often rich in ferns and mosses, fresh sites with moderate to nutrient-rich soils, colline to montane altitudes

91D0 Bog forest, Vaccinium uliginosum - Pinus rotundata, low-growing and light woodland, moderate wet to wet peat, often in sinks, colline to montane altitudes

91E0 Floodplain forest, Alnus glutinosa-Fraxinus excelsior, marshy and wet sites or along streams and trickles, base-rich soils, planar to colline altitudes

sum

\begin{tabular}{|c|c|c|}
\hline 562.01 & 100.81 & 17.94 \\
\hline 25.57 & 2.10 & 8.22 \\
\hline 223.24 & 15.91 & 7.13 \\
\hline 47.83 & 1.62 & 3.39 \\
\hline 59.02 & 2.29 & 3.88 \\
\hline $1,368.31$ & 8.40 & 0.61 \\
\hline $1,24.65$ & 0.94 & 0.75 \\
\hline $1,735.13$ & 4.74 & 0.27 \\
\hline $1,202.34$ & 0.58 & 0.05 \\
\hline $1,123.54$ & 0.34 & 0.03 \\
\hline $6,471.64$ & 137.75 & 2.13 \\
\hline 313.16 & 34.53 & 11.03 \\
\hline $3,348.27$ & 133.05 & 3.97 \\
\hline 105.25 & 0.85 & 0.81 \\
\hline 821.89 & 4.31 & 0.52 \\
\hline $1,616.62$ & 7.20 & 0.45 \\
\hline $2,390.82$ & 10.75 & 0.45 \\
\hline 126.54 & 0.29 & 0.23 \\
\hline 531.93 & 0.81 & 0.15 \\
\hline $1,639.14$ & 1.95 & 0.12 \\
\hline $10,893.72$ & 193.74 & 1.78 \\
\hline
\end{tabular}

Red oak

9190 Oak forest; Quercus petraea-Fagus sylvatica, sandy, moderate dry sites of the lowlands with base poor soils, planar altitudes

9160 Oak forest; Carpinus betulus-Quercus robur (special type with Stachys sylvativa), moderate fresh, moderate wet, or periodically wet sites, planar to montane altitudes

9110 Beech forest; Deschampsia flexuosa-Fagus sylvatica, moderate fresh to moderate dry sites with base-poor soils, planar altitudes

91E0 ${ }^{\mathrm{b}} \quad$ Swamp forest; Prunus padus-Alnus glutinosa-Fraxinus excelsior, special type $^{1}=$ alluvial forest, near groundwater and periodically flooded sites with nutrient-rich soils

9130 Beech forest; Galium odoratum - Fagus sylvatica, moderate fresh sites with moderate base rich and lime-free soils, colline to montane altitudes

9180 Slope forest; Acer spec.-Fraxinus excelsior, deciduous forest on ravines and steep slopes, moderate fresh to wet sites, planar to montane altitudes

9170 Oak forest; Carpinus betulus-Quercus petraea with Galium sylvaticum, periodically dry sites with clay soils, small-areas on very dry sites with limy soils, planar to montane altitudes

- $\quad$ Oak forest; Quercus petraea — Luzula sylvatica, moderate dry sites with acidic sandy soils and gravel, colline to montane altitudes

- $\quad$ Swamp forest; Prunus padus_Alnus glutinosa-Fraxinus excelsior, swamp forest, wet sites, sometimes flooded, planar altitudes

sum

${ }^{a}$ This is the size of the total habitat area where natural regeneration has been reported, but not the size of the actual area being invaded by Douglas fir or red oak

${ }^{\mathrm{b}}$ FFH 91E0 only assigned to special characteristics of this forest habitat in Natura 2000 areas (Kerner and Geisel 2017) 

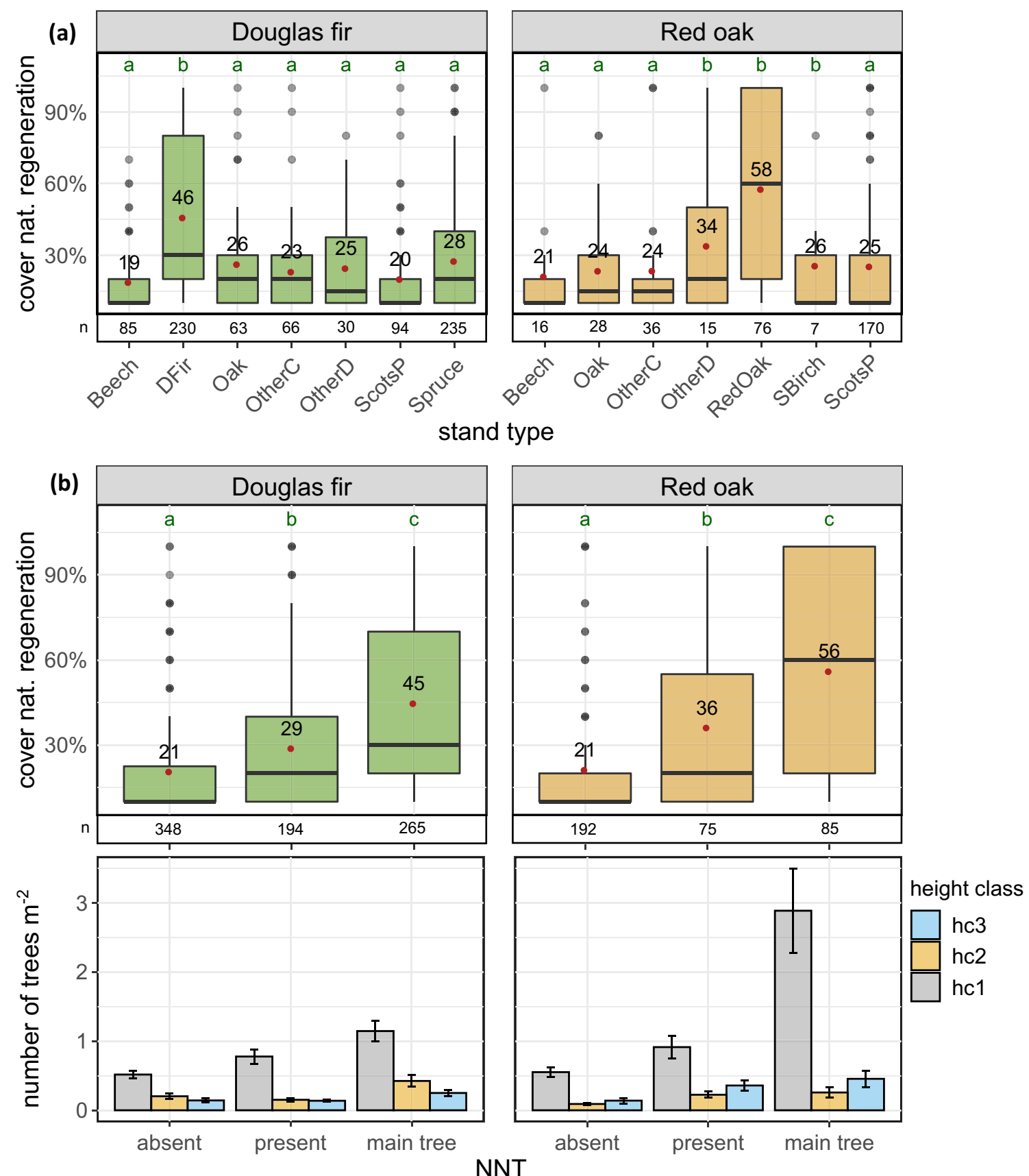

Fig. 2 Natural regeneration of Douglas fir and red oak in different forest types across Germany $\left(\mathrm{NFI}_{2012}\right)$ : a regeneration cover in different stand types, b) regeneration cover and number of seedlings per $\mathrm{m}^{2}$ in height classes in relation to the presence or absence of the non-native tree species itself as a canopy tree. Error bars represent standard error of the mean,' $n$ ' represents number of inventory

plots. DFir $=$ Douglas fir, Oak $=$ sessile and pedunculate oak, OtherC $=$ other conifers, OtherD $=$ other deciduous trees, $\mathrm{Scots} P=$ Scots pine, SBirch=silver birch; NNT, non-native tree species. Height classes: $\mathrm{hc} 1=20-50 \mathrm{~cm}, \mathrm{hc} 2=50.1-130 \mathrm{~cm}, \mathrm{hc} 3=>130 \mathrm{~cm} \&$ $\mathrm{DBH}<7 \mathrm{~cm}$

of roe deer, the most important browsing ungulate (Harmer and Gill 2000).

Although there is an indication that Douglas fir and red oak were able to spread to new locations, regeneration cover and number of saplings were noticeably more abundant at sites where both NNT were canopy species. Consequently,

propagule pressure had an important influence on the establishment success of both NNT which was also found in other studies (e.g. Eggert 2014; Hafner and Wohlgemuth 2017; Major et al. 2013; Woziwoda et al. 2018). In contrast, low importance of propagule source in the establishment success would suggest effective long-distance dispersal of a tree 

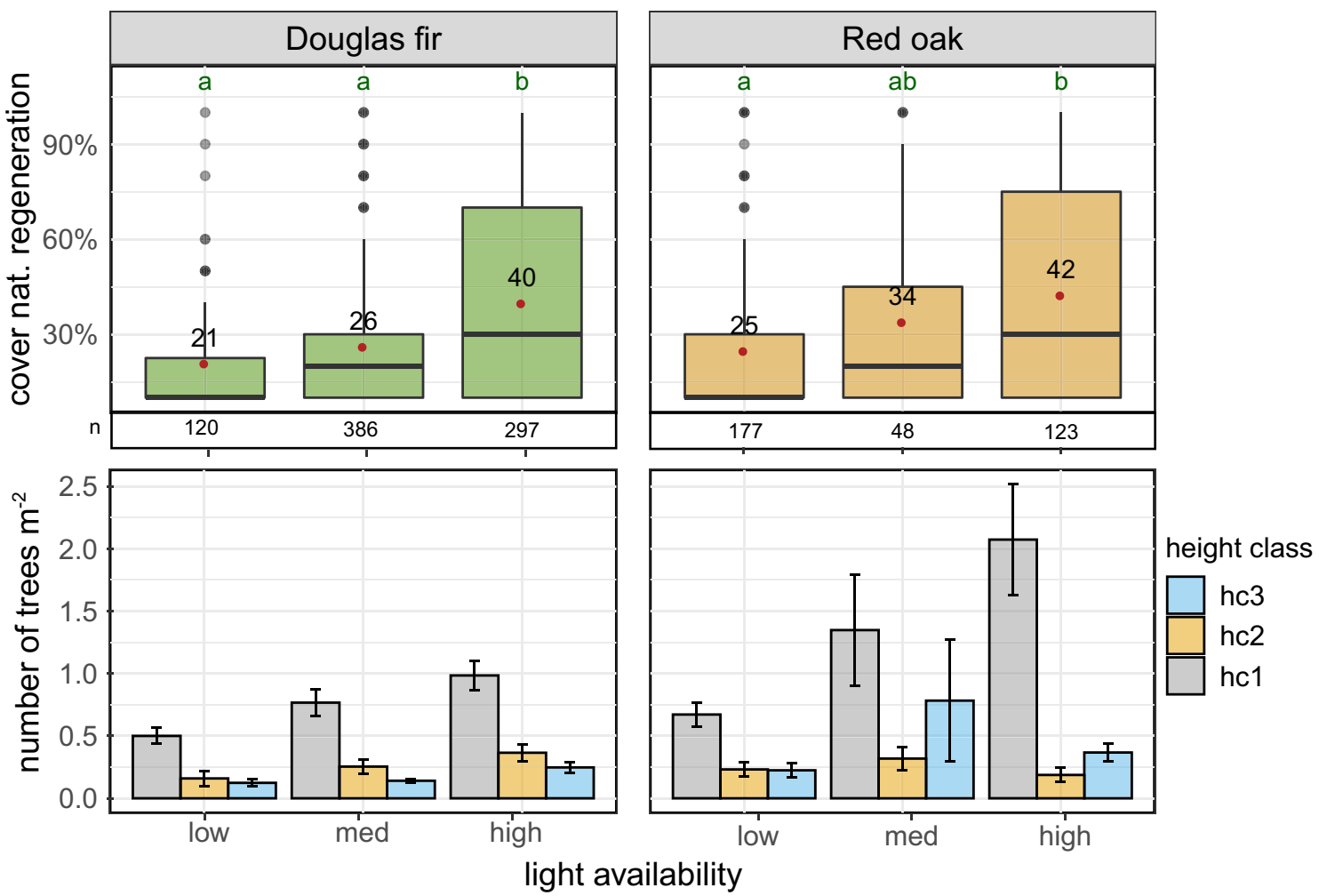

Fig. 3 Natural regeneration of Douglas fir and red oak in Germany $\left(\mathrm{NFI}_{2012}\right)$ : Regeneration cover and number of seedlings per $\mathrm{m}^{2}$ in height classes over light conditions in the understory. Error bars

species (Dyderski and Jagodziński 2018). Hence, the spreading potential of Douglas fir and red oak appeared low in German forests, supporting the assessments by Vor et al. (2015). However, this contrast with results from studies in Poland, Netherlands, and Belgium reporting that red oak is becoming widespread (Chmura 2013; Oosterbaan and Olsthoorn 2005; Vansteenkiste et al. 2005). These divergent outcomes may be explained by larger shares of red oak in the total forest growing stock (e.g. up to 6\% in Belgium) (Vansteenkiste et al. 2005). Also, most studies reporting an increase in red oak natural regeneration were conducted in Scots pine or oak-Scots pine forests where this tree species has frequently been planted in the past and where site conditions are highly suitable for its establishment (e.g. Woziwoda et al. 2018).

When evaluating the establishment success of the species in German forest, it is important to consider the history and goals of forest management. In most cases where the two species form the dominant tree, natural regeneration is typically desired, particularly within the widely adopted concept of close-to-nature forest management (Bauhus et al. 2013). In close-to-nature forestry, where management relies as much as possible on natural processes including regeneration, the selection of NNT even considered the ability to regenerate naturally as a positive criterion (Pro Silva 2012). represent standard error of the mean,'n' represents number of inventory plots. Height classes: hc1 $=20-50 \mathrm{~cm}$, hc2 $=50.1-130 \mathrm{~cm}$, $\mathrm{hc} 3=>130 \mathrm{~cm} \& \mathrm{DBH}<7 \mathrm{~cm}$

In this context, advance regeneration is encouraged by forest management practices such as thinning to provide enough light in the understorey (Kohnle et al. 2019; Major et al. 2013). Yet, regeneration is often hampered in dense forest stands. For example, Douglas fir regeneration decreased in forest stands in the Black Forest because it is less competitive than beech and silver fir although its regeneration is actively promoted and the species dominates the canopy (Steinmetz and Bauhus 2016).

Light conditions are mentioned in literature as being important for the NNT regeneration and competiveness (Broncano et al. 2005; Schmid et al. 2014; Vansteenkiste et al. 2005; Woziwoda et al. 2018). The importance of this factor was confirmed by our study showing relatively little establishment in forest stands dominated by shade-tolerant tree species and hence low light availability and competition from seedlings and saplings of more shade-tolerant species. In particular in closed European beech stands, Douglas fir and red oak seedlings would be naturally outcompeted in the long-term (Nagel 2015; Spellmann et al. 2015). Our analysis showed that high light availability such as in stands composed of Scots pine, birch or larch increased establishment success of both NNT. Yet, both species are frequently considered to be moderately shade-tolerant in Europe (Nicolescu 

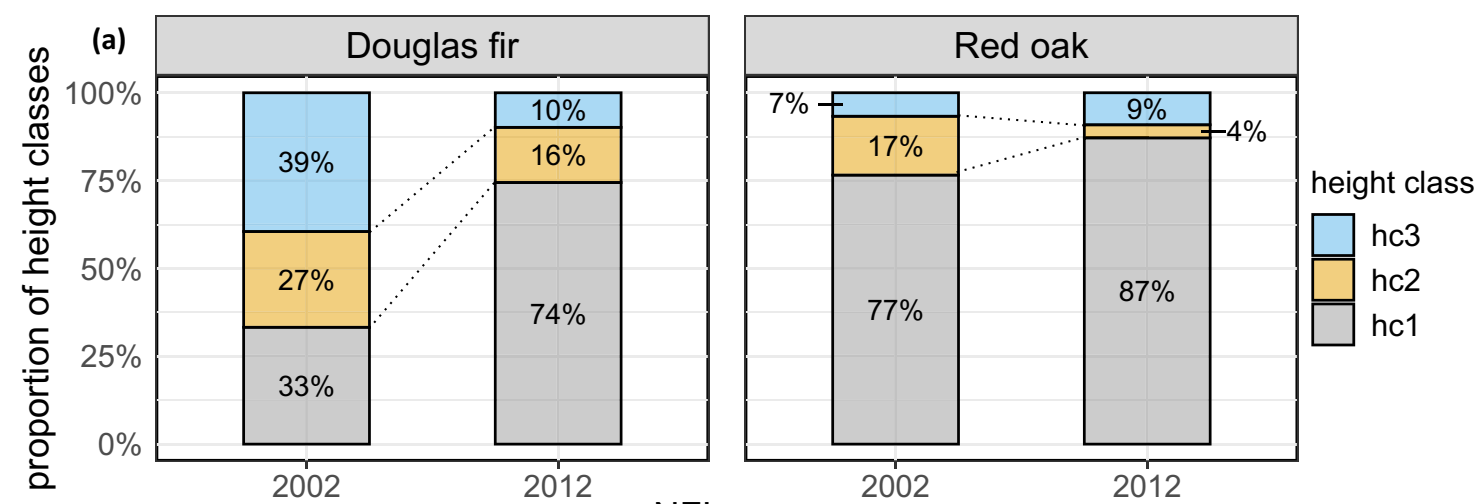

(b)

NFI year



Fig. 4 Temporal changes in recorded Douglas fir and red oak seedlings in Germany $\left(\mathrm{NFI}_{2002}, \mathrm{NFI}_{2012}\right)$. a Proportion of individuals sampled in the different height classes, $\mathbf{b}$ total number of inventory plots where different height classes were recorded. Height classes: $\mathrm{hc} 1=20-50 \mathrm{~cm}, \mathrm{hc} 2=50.1-130 \mathrm{~cm}, \mathrm{hc} 3=>130 \mathrm{~cm} \& \mathrm{DBH}<7 \mathrm{~cm}$
Fig. 5 Map of the State of Baden-Württemberg (southwest Germany) with distribution of protected forest habitats where natural regeneration of Douglas fir and red oak has been reported (Selective Forest Habitat Mapping 2019)

2019; Nicolescu et al. 2018). Here, the number of plots with medium light availability carrying red oak regeneration was surprisingly low, which is in contrast to the studies indicating a higher shade tolerance of $Q$. rubra, particularly up to the age of 10 years (Kuehne et al. 2014; Major et al. 2013; Vor 2005). Our relatively coarse classification of light availability is not suited to identify the optimal light regime for the two NNT and to disentangle the importance of light from that of other site factors, such as local calamities, browsing pressure, competition, ground vegetation structure, or the soil properties (Kremer and Bauhus 2020). However, there is no information on the local expression of these variables to be gained from the NFI data. Likewise, NFI plot data do not provide information about size and distribution of gaps within stands. Nevertheless, forest sites with high availability of light can be considered more invasible than those with low availability.

The assessment of NNT establishment in protected habitats in south-west Germany showed that, in accordance with the NFI data, regeneration was predominantly found in forests with low canopy density and sparse understory, such as in different oak forest communities (both NNT) or rocky outcrops with sparse tree cover (Douglas fir). In these ecosystem types, which cover only very small areas, lack of competitive tree species presumably provides suitable conditions for establishment. Red oak is best adapted to acidic, sandy, loamy, and well-drained soils (Nicolescu et al. 2018). In south-west Germany, such conditions can be found in the Rhine valley where red oak has been widely cultivated (forest management plan, ForstBW) leading to a high propagule pressure on protected forest habitats near-by (e.g. habitat type 9190) (LUBW 2020). For example, forest stands dominated by red oak have been identified in the surrounding (i.e. $1 \mathrm{~km}$ ) of about $80 \%$ of the habitat reserves with recorded red oak natural regeneration in the south-west of Germany (Miocic 2019). In some parts of the Black forest, Douglas fir accounts for more than $10 \%$ of the forest area (Oberer 2011) likely to increase the risk of spread into more open forest habitats in this region (LUBW 2020). The establishment and growth of both NNT is negatively affected by calcareous soils (Nicolescu et al. 2018; Norris et al. 2015), which explains the lack of regeneration of the two species in forest habitats on such soils. The absence of natural regeneration of the two NNT in the Swabian Alb lime-stone plateau region is likely also the result of little past cultivation and hence lack of propagules.

\section{Temporal patterns in tree regeneration between 2002 and 2012}

Whilst Douglas fir has already increased its mean regeneration cover, there was no significant increase in red oak. However, the number of inventory plots with saplings increased in both NNT meaning that they have successfully established themselves. In forest stands, Douglas fir typically starts producing significant quantities of seeds at about 30 years of age (Appelfelder 1999) and red oak at about 20 to 25 years of age, although most trees do not produce acorns in large quantities until 40 to 50 years (USDA 2000). The forest area (ha) with trees older than 40 years increased by $44 \%$ for red oak and by 88\% for Douglas fir from 2002 to 2012. Therefore, the increase in naturally regenerated Douglas fir and red oak trees, particularly the ones smaller than $50 \mathrm{~cm}$, is probably associated with increasing propagule pressure through maturing stands of the two species rather than an indication for range expansion.

Natural regeneration of both NNT may have also been promoted through natural disturbances that have continuously increased in European forests in the last decades (Seidl et al. 2014), potentially promoting more light-demanding tree species (e.g.Maringer et al. 2012). In this context, the establishment of Douglas fir and red oak may be further stimulated because disturbances caused by insects and droughts are likely to increase under warmer and drier future conditions (Seidl et al. 2017). In addition, artificial regeneration may have been incorrectly classified as natural regeneration in some cases. In uneven-aged and mixed forests managed according to close-to-nature forestry principles, natural regeneration is often complemented by planting of some seedlings of desired species at wide spacing or in small groups. For inventory staff without local management records, the surviving planted trees are not always discernible from natural regeneration. Conversely, it is unlikely that naturally regenerated trees are being considered as planted.

\section{Habitats at risk and management recommendations}

Semi-natural forests on poor sites with less competitive tree species and sufficient light in the understory which are located near stands with sexually mature Douglas fir and red oak can be considered most sensitive to invasion. In these cases establishment is likely and may potentially change site conditions and native species composition (e.g. Budde 2006; Knoerzer 1999; Woziwoda et al. 2014). Douglas fir and red oak are more competitive than European oaks, and if no management is applied, they may become dominant (Cocking et al. 2015; Nagel 2015; Spellmann et al. 2015). To date, there has been no quantitative documentation on the actual extent of Douglas fir and red oak establishments (e.g. abundance) in protected forest habitats in south-west Germany because collecting such data is not a part of the routine monitoring. The recorded presence or absence contains no information about stage of establishment and the actual risk. Therefore, it remains unknown whether these NNT have the actual potential for reaching dominance. Moreover, in Germany, natural regeneration of native oaks 
is poor in general because it is subject to intensive browsing (Kohler et al. 2020). Additionally, semi-natural oak forests occur often in areas of potential beech forests where oaks are at risk of being outcompeted by beech during forest succession (Annighöfer et al. 2015). For example, the establishment success of Douglas fir was low in Luzulo-Quercetum habitats located in the Black forest and the typical tree species were threatened by native silver fir and beech rather than Douglas fir (Heintze 2018). Thus, more research and improved monitoring in sensitive forest types is necessary to better understand the (long-term) effects of NNT establishment. Regardless of the possible successional dynamics, regeneration of the two NNT (or any other non-typical species) is not desired in areas of high conservation value (e.g. ForstBW 2015). Therefore, management of stands with Douglas fir and red oak should consider susceptible ecosystem types in the landscape and prevent spread. Management approaches could involve appropriate buffer zones around sensitive ecosystem types (e.g. $300 \mathrm{~m}$ for Douglas-fir ForstBW 2014) and regular stem removal of undesired regeneration in protected areas. Mechanical stem removal is feasible since both NNT do no regenerate vegetatively by root suckers and thus carry a lower risk to establish permanent populations like other NNT (e.g. black locust) (Meyer-Münzer et al. 2015). Regular revisits may be required because red oak is able to re-sprout from the stump (Oosterbaan and Olsthoorn 2005). There is an urgent need for data on dispersal distances to provide evidence-based recommendations for establishing appropriate buffer zones. One study conducted in North America reported that most wind-dispersed Douglas fir seeds fall within $100-150 \mathrm{~m}$ to the ground; in rare cases they may travel up to $2000 \mathrm{~m}$ (Dick 1955). In case of red oak, seeds are dispersed by gravity (very limited spread) and animals, where dispersal distances range between $150 \mathrm{~m}$ and 4 km (Dreßel and Jäger 2002; Nagel 2015; Riepðas and Straigytë 2008). The long-distance dispersal by birds such as the Eurasian Jay (Garrulus glandarius L.) makes it difficult to implement effective buffer zones. Although, natural regeneration of both NNT currently occurs at a rather low level in protected forest habitats in south-west Germany, risk management should be taken seriously since the quantity of propagules in the existing stands will likely increase in the future. Moreover, new stands with Douglas fir and red oak can be expected in future as a number of commercially important native tree species are increasingly affected by pests, drought and increasing temperatures (Allen et al. 2010). Yet, current populations of these tree species will also disappear from parts of the landscape, where they are deemed unsuitable, for example because of storm damages, severe drought impacts or pest and pathogen damages (e.g. Albrecht et al. 2013; Schäfer-Penzel and Schumacher 2015). Therefore, dynamics of spatial distribution of both NNT should be carefully monitored in the future.

\section{Limitations of using forest inventories in risk assessments}

Whilst the large-scale inventory design facilitates analysis of strata such as forest types, NFI data do not sufficiently well capture all relevant aspects and areas of high conservation value, which are often rare and cover only a small area (e.g. Kerner and Geisel 2017). Some important variables determining the invasiveness of NNT can only be addressed through surrogates (e.g. light availability, spread potential). Other factors such as dispersal distances cannot be quantified owing to the lack of spatially explicit information. Overall, Douglas fir and red oak are still rare tree species in Germany resulting in small numbers of inventory plots with these species. This small data basis limits the power of statistical analyses and thus the reliability of findings. Assuming a random distribution of a tree species in the inventory area, sampling error increases with decreasing grid density and decreasing occurrence of a tree species. As a measure of reliability, sampling errors are calculated for major tree species in the German NFI (Klemmt and Neubert 2011). For example, at the national level the relative sampling error at the $68 \%$ confidence limit of Douglas fir is 2.6 times higher $(\mathrm{SE}[\%]=3.4)$ than the sampling error of Norway spruce $(\mathrm{SE}[\%]=1.3)$ (https://bwi.info; 77Z1JI_L235of_2012_bi / 2014-6-10 16:7:59.927). Given the current limitations, one might consider modifying the NFI protocol to better capture rare events such as regeneration of NNT through establishing larger regeneration plots or through transect sampling between inventory plots (e.g. Bäuerle et al. 2009).

Also, the small number of recorded forest habitats with natural regeneration, especially for red oak, combined with missing information on the actual extent of the NNT establishment prevents meaningful significance testing to derive reliable information on the actual risks posed by both NNT. For example, it could not be clarified if Douglas fir and red oak have spread into specific forest habitats because of high propagule pressure and/or because the habitat is particularly sensitive to invasion. In addition, the perception and qualitative recording of invasion risks is subjective and therefore inconsistent. Consequently the number of protected habitats with established NNT may be higher than originally indicated (e.g. Hys 2018).

\section{Conclusion}

This is one of the first studies in Europe that analyses systematic forest inventory data to assess natural regeneration of NNT in different forest types to carry out a risk assessment. Based on the large-scale assessment, we found no evidence for high establishment and spread potentials of Douglas fir and red oak seedlings in the majority of forests in Germany. Establishment success of both NNT was 
influenced by tree species composition, light conditions, and the presence and dominance of NNT in the canopy. In semi-natural forests with sufficient light in the understory and less competitive native trees, both NNT can establish and may cause changes in species compositions. Responsible management of Douglas fir and red oak can deliver benefits with limited risks of invasiveness, if propagule sources close to sensitive ecosystems are removed, for example by installing appropriate buffer zones, and initial establishments in sensitive ecosystems are prevented. Such changes in management might be controversial and engagement with diverse stakeholders on the invasion risks posed by NNT and on the options for their management is recommended (Brundu et al. 2020). Forest inventories continue to develop and provide increasing detail with every inventory period and thus could help track NNT invasion trends at national and regional scale. Therefore, our approach may be applied to NFIs of other countries, also to compare the risks of establishment and spread of NNT amongst ecosystem types in different regions or jurisdictions. For this purpose, it is important that presence and abundance of all tree species in the regeneration layer are recorded. Particularly, regional data on protected areas have a great potential for supporting risk assessments of NNT since they may provide spatially explicit information on sensitive ecosystem types. However, largescale inventories will be only useful for species that have reached a certain distribution already; they are not helpful for early detection in risk assessment approaches.

Supplementary Information The online version contains supplementary material available at https://doi.org/10.1007/s10342-021-01373-0.

Acknowledgements Many thanks to Tineke Materne for collecting the information on existing inventories and methods of monitoring protected forest habitats in the different states of Germany. We are grateful to Jeannine Slowik who evaluated the habitat descriptions and surveyor comments of the Selected Forest Habitat Mapping. The FVA is acknowledged for providing data on the protected forest habitats in the State of Baden-Württemberg. We thank Gerald Kändler and Petra Hennig for support in all NFI-related questions.

Funding Open Access funding enabled and organized by Projekt DEAL.

Open Access This article is licensed under a Creative Commons Attribution 4.0 International License, which permits use, sharing, adaptation, distribution and reproduction in any medium or format, as long as you give appropriate credit to the original author(s) and the source, provide a link to the Creative Commons licence, and indicate if changes were made. The images or other third party material in this article are included in the article's Creative Commons licence, unless indicated otherwise in a credit line to the material. If material is not included in the article's Creative Commons licence and your intended use is not permitted by statutory regulation or exceeds the permitted use, you will need to obtain permission directly from the copyright holder. To view a copy of this licence, visit http://creativecommons.org/licenses/by/4.0/.

\section{References}

Albrecht A, Kohnle U, Hanewinkel M, Bauhus J (2013) Storm damage of Douglas-fir unexpectedly high compared to Norway spruce. Ann For Sci 70:195-207. https://doi.org/10.1007/ s13595-012-0244-x

Allen CD et al (2010) A global overview of drought and heat-induced tree mortality reveals emerging climate change risks for forests. For Ecol Manage 259:660-684. https://doi.org/10.1016/j.foreco. 2009.09.001

Ammer C et al (2014) Offenener Brief deutscher Forstwissenschaftler vom 4. Juni 2014 an das BfN: Erhebliche Zweifel an der naturschutzfachlichen Invasivitätsbewertung einiger forstlich relevanter Baumarten. AFZ-DerWald 69:12-14

Annighöfer P, Beckschäfer P, Vor T, Ammer C (2015) Regeneration patterns of European oak species (Quercus petraea (Matt.) Liebl., Quercus robur L.) in dependence of environment and neighborhood. PLoS ONE 10:e0134935-e0134935. https://doi.org/10. 1371/journal.pone.0134935

Appelfelder J (1999) Anmerkungen zur konkurrenzsituation der naturverjüngung und der ausbreitung der douglasie (Pseudotsuga menziesii) im naturschutzgebiet lüneburger heide. Georg August Universität Göttingen, Diplom

Aven T (2011) On different types of uncertainties in the context of the precautionary principle. Risk Anal 31:1515-1525. https:// doi.org/10.1111/j.1539-6924.2011.01612.x

Bartz R, Kowarik I (2019) Assessing the environmental impacts of invasive alien plants: a review of assessment approaches. NeoBiota. https://doi.org/10.3897/neobiota.43.30122

Bäuerle H, Nothdurft A, Kändler G, Bauhus J (2009) Biodiversitätsmonitoring auf basis von stichproben. Forst- u Jagdzeitschrift 180:249-260

Bauhus J, Puettmann KJ, Kuehne C (2013) Close-to-nature forest management in Europe: does it support complexity and adaptability of forest ecosystems? In: Messier C, Puettmann KJ, Coates KD (eds) Managing forests as complex adaptive systems: building resilience to the challenge of global change. The Earthscan Forest Library edn, Routledge, New York, USA, pp 187-213

Bequet R, Kint V, Campioli M, Vansteenkiste D, Muys B, Ceulemans R (2012) Influence of stand, site and meteorological variables on the maximum leaf area index of beech, oak and Scots pine. Eur J Forest Res 131:283-295. https://doi.org/10.1007/ s10342-011-0500-x

Bindewald A, Michiels H-G (2018) Invasivität der Douglasie in Südwestdeutschland: Waldinventurdaten erlauben eine Einschätzung. Schweiz Z Forstwes 169:86-92. https://doi.org/10.3188/ szf.2018.0086

Bindewald A, Michiels H-G, Bauhus J (2019) Risk is in the eye of the assessor: comparing risk assessments of four non-native tree species in Germany. Forestry. Int J Forest Res. https://doi.org/ 10.1093/forestry/cpz052

Bindewald A, Michiels H-G, Bauhus J (2020) Risk is in the eye of the assessor: comparing risk assessments of four non-native tree species in Germany. Forestry. Int J Forest Res 93:519-534. https:// doi.org/10.1093/forestry/cpz052

BMEL (2012) National forest inventory. Thünen Institut, Bundesministerium für Ernährung und Landwirtschaft. https://bwi.info/. Accessed 30 January 2019

BMEL (2018) Der Wald in Deutschland - Ausgewählte Ergebnisse der dritten Bundeswaldinventur, vol 3. Bundesministerium für Ernährung und Landwirtschaft, Frankfurt am Main, Germany

Bolte A et al (2009) Adaptive forest management in central Europe: climate change impacts, strategies and integrative concept. Scand J 
For Res 24:473-482. https://doi.org/10.1080/028275809034182 24

Broncano MJ, Vila M, Boada M (2005) Evidence of Pseudotsuga menziesii naturalization in montane Mediterranean forests. For Ecol Manage 211:257-263. https://doi.org/10.1016/j.foreco.2005.02. 055

Brundu G, Richardson DM (2016) Planted forests and invasive alien trees in Europe: A Code for managing existing and future plantings to mitigate the risk of negative impacts from invasions. NeoBiota 30:5-47. https://doi.org/10.3897/neobiota.30.7015

Brundu G et al (2020) Global guidelines for the sustainable use of nonnative trees to prevent tree invasions and mitigate their negative impacts. NeoBiota 61:65-116. https://doi.org/10.3897/neobiota. 61.58380

Brus R, Pötzelsberger E, Lapin K, Brundu G, Orazio C, Straigyte L, Hasenauer H (2019) Extent, distribution and origin of nonnative forest tree species in Europe. Scand J For Res 34:533-544. https://doi.org/10.1080/02827581.2019.1676464

Budde S (2006) Auswirkungen des Douglasienanbaus auf die Bodenvegetation im nordwestdeutschen Tiefland. Cuvillier Verlag Göttingen, Göttingen, Germany

Campagnaro T, Brundu G, Sitzia T (2018) Five major invasive alien tree species in European Union forest habitat types of the Alpine and Continental biogeographical regions. J Nat Conserv 43:227238. https://doi.org/10.1016/J.JNC.2017.07.007

Castro-Díez P et al (2019) Global effects of non-native tree species on multiple ecosystem services. Biol Rev 94:1477-1501. https://doi.org/10.1111/brv.12511

Chmura D (2013) Impact of alien tree species Quercus rubra L. on understorey environment and flora: a study of the Silesian Upland (Southern Poland). Polish J Ecol 61:431-441

Chytrý M, Maskell LC, Pino J, Pyšek P, Vilà M, Font X, Smart SM (2008) Habitat invasions by alien plants: a quantitative comparison amongst Mediterranean, subcontinental and oceanic regions of Europe. J Appl Ecol 45:448-458. https://doi.org/ 10.1111/j.1365-2664.2007.01398.x

Cocking MI, Varner JM, Engber EA (2015) Conifer encroachment in California oak woodlands. In: Standiford R, Purcell K (eds) Proceedings of the seventh California oak symposium: managing oak woodlands in a dynamic world Gen Tech Rep PSWGTR-251. Department of Agriculture, Forest Service, Pacific Southwest Research Station, Berkeley CA, USA, pp 505-514

Davis MA et al (2011) Don't judge species on their origins. Nature 474:153-154. https://doi.org/10.1038/474153a

De Avila A, Albrecht A (2018) Alternative Baumarten im Klimawandel: Artensteckbriefe - eine Stoffsammlung. Forstliche Versuchs- und Forschungsanstalt Baden-Württemberg (FVA), Freiburg, Germany

Dick JTA (1955) Studies of Douglas fir seed flight in south western Washington. Weyerhaeuser Timber Company Tacoma, USA

Dickie IA et al (2014) Conflicting values: ecosystem services and invasive tree management. Biol Invasions 16:705-719. https:// doi.org/10.1007/s 10530-013-0609-6

Dodet M, Collet C (2012) When should exotic forest plantation tree species be considered as an invasive threat and how should we treat them? Biol Invasions 14:1765-1778. https://doi.org/10. 1007/s10530-012-0202-4

Dreßel R, Jäger EJ (2002) Beiträge zur Biologie der Gefäßpflanzen des herzynischen Raumes. 5. Quercus rubra L. (Roteiche): Lebensgeschichte und agriophytische Ausbreitung im Nationalpark Sächsische Schweiz. Hercynia 35:37-64

Dyderski MK, Jagodziński AM (2018) Drivers of invasive tree and shrub natural regeneration in temperate forests. Biol Invasions 20:2363-2379. https://doi.org/10.1007/s10530-018-1706-3

Eggert M (2014) Die Douglasie in Bayern (1. Teil): Wie verjüngt sich die Douglasie? AFZ-Der Wald 11:27-29
Forst BW Datenbank Forsteinrichtung Baden-Württemberg

ForstBW, (2014) Richlinie landesweiter Waldentwicklungstypen. Landesbetrieb Forst Baden-Württemberg, Stuttgart, Germany

ForstBW, (2015) Gesamtkonzeption Waldnaturschutz ForstBW. Landesbetrieb Forst Baden-Württemberg, Stuttgart, Germany

Givnish T (1988) Adaptation to sun and shade: a whole-plant perspective. Funct Plant Biol 15:63-92. https://doi.org/10.1071/ PP9880063

Hafner J, Wohlgemuth T (2017) DICE-risk: Potenzielle Invasivität der Douglasie in der Schweiz: Eine standortsbezogene Evaluation. Schlussbericht im Forschungsprogramm "Wald und Klimawandel" des Bundesamtes für Umwelt und der Eidg Forschungsanstalt WSL. ETH Zurich, Eidg. Forschungsanstalt für Wald, Schnee und Landschaft WSL, Birmensdorf, Switzerland. doi:https://doi.org/https://doi.org/10.3929/ethzb-000232952

Harmer R, Gill R (2000) Natural regeneration in broadleaved woodlands: deer browsing and the establishment of advance regeneration. Forestry Commission information note, vol 35. Forestry Commission, Edinburgh, Scotland

Hawkins CL et al (2015) Framework and guidelines for implementing the proposed IUCN Environmental Impact Classification for Alien Taxa (EICAT). Divers Distrib 21:1360-1363. https:// doi.org/10.1111/ddi.12379

Heintze M (2018) Der Einfluß der Douglasie auf Hainsimen-Traubeneichen-Wälder im Bergwald des Stadtwaldes Freiburg. Bachelor of Science, HAWK Hochschule Göttingen

Holgate P (1967) The angle-count method. Biometrika 54:615-623. https://doi.org/10.1093/biomet/54.3-4.615

Hulme PE, Pyšek P, Jarošík V, Pergl J, Schaffner U, Vilà M (2013) Bias and error in understanding plant invasion impacts. Trends Ecol Evol 28:212-218. https://doi.org/10.1016/j.tree.2012.10.010

Hys G (2018) Standort, Vegetation und Gehölzverjüngung der Traubeneiche im Westschwarzwald. Master Thesis, University of Freiburg

Kerner A, Geisel M (2017) Waldbiotopkartierung Baden-Württemberg - Kartierhandbuch FVA, vol 11. Forstliche Versuchs- und Forschungsanstalt Baden-Württemberg, Freiburg, Germany

Klemmt J, Neubert M (2011) Möglichkeiten und Grenzen der Auswertbarkeit der BWI3 in Bayern. LWF aktuell 85:44-46

Knoerzer D (1999) Zur Naturverjüngung der Douglasie im Schwarzwald - Inventur und Analyse von Umwelt- und Konkurrenzfaktoren sowie eine naturschutzfachliche Bewertung. Dissertationes Botanicae, vol 306. Gebrüder Borntraeger Verlagsbuchhandlung, Stuttgart, Germany

Kohler M, Pyttel P, Kuehne C, Modrow T, Bauhus J (2020) On the knowns and unknowns of natural regeneration of silviculturally managed sessile oak (Quercus petraea (Matt.) Liebl.) forests—a literature review. Ann For Sci 77:1-19. https://doi.org/10.1007/ s13595-020-00998-2

Kohnle U, Klädtke J, Chopard B (2019) Management of Douglas-fir and technological properties of its wood. In: Spiecker H, Lindner M, Schuler J (eds) Douglas-fir - an option for Europe. European Forest Institute, Joensuu, Finland, pp 73-83

Kovac M, Gasparini P, Notarangelo M, Rizzo M, Cañellas I, Fernández-de-Uña L, Alberdi I (2019) Towards a set of national forest inventory indicators to be used for assessing the conservation status of the Habitats Directive forest habitat types. J Nat Conserv. https://doi.org/10.1016/j.jnc.2019.125747

Kremer KN, Bauhus J (2020) Drivers of native species regeneration in the process of restoring natural forests from mono-specific, even-aged tree plantations: a quantitative review. Restor Ecol 28:1074-1086. https://doi.org/10.1111/rec.13247

Krumm F, Vítková L (2016) Introduced tree species in European forests: opportunities and challenges. European Forest Institute, Freiburg, Germany 
Kuehne C, Nosko P, Horwath T, Bauhus J (2014) A comparative study of physiological and morphological seedling traits associated with shade tolerance in introduced red oak (Quercus rubra) and native hardwood tree species in southwestern Germany. Tree Physiol 34:184-193. https://doi.org/10.1093/treephys/tpt124

Latombe $\mathrm{G}$ et al (2016) A vision for global monitoring of biological invasions. Biol Conserv. https://doi.org/10.1016/j.biocon.2016. 06.013

Liu H (2015) Comparing Welch's ANOVA, a Kruskal-Wallis test and traditional ANOVA in case of Heterogeneity of Variance. Master Thesis, Virginia Commonwealth University

Lockwood JL, Cassey P, Blackburn T (2005) The role of propagule pressure in explaining species invasions. Trends Ecol Evol 20:223-228. https://doi.org/10.1016/j.tree.2005.02.004

LUBW (2020) Übersicht Biotoptypen Baden-Württemberg. https:// www.lubw.baden-wuerttemberg.de/natur-und-landschaft/ueber sicht-biotoptypen?p_p_id=101_INSTANCE_YeDtqIcvHK so\&p_p_lifecycle $=0 \& p \_p \_c o l \_i d=$ column-2\&p_p_col_count $=$ 3\&p_r_p_564233524_resetCur=true\&p_r_p_564233524_categ oryId=373456. Accessed 31 August 2020

Major KC, Nosko P, Kuehne C, Campbell D, Bauhus J (2013) Regeneration dynamics of non-native northern red oak (Quercus rubra L.) populations as influenced by environmental factors: a case study in managed hardwood forests of southwestern Germany. For Ecol Manage 291:144-153. https://doi.org/10. 1016/j.foreco.2012.12.006

Maringer J, Wohlgemuth T, Neff C, Pezzatti GB, Conedera M (2012) Post-fire spread of alien plant species in a mixed broad-leaved forest of the Insubric region. Flora Morphol Distrib Funct Ecol Plants 207:19-29. https://doi.org/10.1016/j.flora.2011.07.016

Meyer-Münzer B, Grotehusmann H, Vor T (2015) Robinie (Robinia pseudoacacia L.). In: Vor T, Spellmann H, Bolte A, Ammer $\mathrm{C}$ (eds) Potenziale und Risiken eingeführter Baumarten Baumartenportaits mit naturschutzfachlicher Bewertung. Universitätsverlag Göttingen, Göttingen, Germany, pp 277-296

Michiels H-G (2014) Überarbeitung der Standortskundlichen Regionalen Gliederung von Baden-Württemberg. Standortwald pp 7-40

Miocic S (2019) Site-specific risk assessment of Quercus rubra L. in Germany - Quantifying invasiveness using national and regional forest inventory data. Master Thesis, Albert-Ludwigs-Universität Freiburg

Montgomery RA (2004) Effects of understory foliage on patterns of light attenuation near the forest floor. Biotropica 36:33-39. https://doi.org/10.1111/j.1744-7429.2004.tb00293.x

Nagel R-V (2015) Roteiche (Quercus rubra L.). In: Vor T, Spellmann H, Bolte A, Ammer C (eds) Potenziale und Risiken eingeführter Baumarten - Baumartenportraits mit naturschutzfachlicher Bewertung). Universitätsverlag Göttingen, Göttingen, Germany, pp 219-267

Nehring S, Kowarik I, Rabitsch W, Essl F (2013) Naturschutzfachliche Invasivitätsbewertungen für in Deutschland wild lebende gebietsfremde Gefäßpflanzen. BfN, Bonn, Germany

Nicolescu V-N et al (2018) Ecology and management of northern red oak (Quercus rubra L. syn. Q. borealis F. Michx.) in Europe: a review. For Int J For Res. https://doi.org/10.1093/forestry/cpy032

Nicolescu V-N (2019) Natural range, site requirements and shade tolerance. In: Spiecker H, Lindner M, Schuler J (eds) Douglas-fir - an option for Europe. European Forest Institute, Joensuu, Finland, pp 33-39

Niinemets Ü, Valladares F (2006) Tolerance to shade, drought, and waterlogging of temperate Northern Hemisphere trees and shrubs. Ecol Monogr 76:521-547. https://doi.org/10.1890/00129615(2006)076[0521:TTSDAW]2.0.CO;2

Norris CE, Maynard DG, Hogg KE, Benton R, Titus BD, Curran MP (2015) Ten-year results of seedling growth on calcareous soils in the interior of British Columbia, Canada. For Ecol Manage 346:65-80. https://doi.org/10.1016/j.foreco.2015.02.036

Oberer F (2011) Douglasie als alternative zur Fichte? Douglasienanbau im Schwarzwald. Wald und Holz 4:32-35

Oosterbaan A, Olsthoorn A (2005) Control strategies for Prunus serotina and Quercus rubra as exotic tree species in the Netherlands. In: Nentwig W, Bacher S, Cock MJW, Dietz H, Gigon A, Wittenberg R (eds) Biological Invasions - From Ecology to Control, vol 6. Neobiota, pp 177-181

Oswalt CM, Fei S, Guo Q, Iannone BV III, Oswalt SN, Pijanowski BC, Potter KM (2015) A subcontinental view of forest plant invasions. NeoBiota 24:49-54

Polley H, Schmitz F, Hennig P, Kroiher F (2010) Germany. In: Tomppo E, Gschwantner T, Lawrence M, McRoberts RE (eds) National forest inventory - pathways for common reporting. Springer, Heidelberg, Dortrecht, London, New York, pp 223-243

Pyšek P (2016) What determines the invasiveness of tree species in central Europe? In: Krumm F, Vitcova L (eds) Introduced tree species in European forests: opportunities and challenges. European Forest Institute, Freiburg, Germany, pp 68-77

Pyšek P, Jarošík V, Hulme PE, Pergl J, Hejda M, Schaffner U, Vilà M (2012) A global assessment of invasive plant impacts on resident species, communities and ecosystems: the interaction of impact measures, invading species' traits and environment. Global Change Biol 18:1725-1737. https://doi.org/10.1111/j. 1365-2486.2011.02636.x

Richardson DM, Pyšek P, Rejmánek M, Barbour MG, Panetta FD, West CJ (2000) Naturalization and invasion of alien plants: concepts and definitions. Divers Distrib 6:93-107. https://doi.org/ 10.1046/j.1472-4642.2000.00083.x

Riepðas E, Straigytë L (2008) Invasiveness and ecological effects of red oak (Quercus rubra L.) in lithuanian forests. Balt For 14:122-130

Rouget M, Richardson DM, Nel JL, Van Wilgen BW (2002) Commercially important trees as invasive aliens: towards spatially explicit risk assessment at a national scale. Biol Invasions 4:397-412. https://doi.org/10.1023/A:1023611713339

Roy HE et al (2018) Developing a framework of minimum standards for the risk assessment of alien species. J Appl Ecol 55:526-538. https://doi.org/10.1111/1365-2664.13025

Sádlo J, Vítková M, Pergl J, Pyšek P (2017) Towards site-specific management of invasive alien trees based on the assessment of their impacts: the case of Robinia pseudoacacia. NeoBiota 35:1-34. https://doi.org/10.3897/neobiota.35.11909

Sapsford SJ et al (2020) Towards a framework for understanding the context-dependence of impacts of non-native tree species. Funct Ecol. https://doi.org/10.1111/1365-2435.13544

Schäfer-Penzel S, Schumacher J (2015) Prüfung der Zukunftsfähigkeit der Douglasie (Pseudotsuga menziesii) aus waldhygienischer Sicht. KLIMOPASS, LUBW Landesanstalt für Umwelt, Messungen und Naturschutz Baden-Württemberg, Karlsruhe, Germany

Schmid M, Pautasso M, Holdenrieder O (2014) Ecological consequences of Douglas fir (Pseudotsuga menziesii) cultivation in Europe. Eur J Forest Res 133:13-29. https://doi.org/10.1007/ s10342-013-0745-7

Schmidt PA (1999) Übersicht der natürlichen Waldgesellschaften Deutschlands. Freistaat Sachsen, Sächsisches Staatsministerium für Landwirtschaft, Tharandt, Germany

Seidl R, Schelhaas M-J, Rammer W, Verkerk PJ (2014) Increasing forest disturbances in Europe and their impact on carbon storage. Nat Clim Change 4:806-810. https://doi.org/10.1038/nclim ate 2318

Seidl R et al (2017) Forest disturbances under climate change. Nat Clim Change 7:395-402. https://doi.org/10.1038/nclimate3303

Pro Silva (2012) Close to nature forestry. https://www.prosilva.org/filea dmin/prosilva/3_Close_to_Nature_Forestry/01_ProSilva_Princ iples/Pro_Silva_Principles_2012.pdf. Accessed 6th Nov 2020 
Spellmann H, Weller A, Brang P, Michiels H-G, Bolte A (2015) Douglasie (Pseudotsuga menziesii (Mirb.) Franco). In: Vor T, Spellmann H, Bolte A, Ammer C (Eds) Potenziale und Risiken eingeführter Baumarten - Baumartenportraits mit naturschutzfachlicher Bewertung, vol 7. Göttinger Forstwissenschaften. Universitätsverlag Göttingen, Göttingen, Germany, pp 187-217

Steinmetz A, Bauhus J (2016) Naturverjüngung der Douglasie im Stadtwald Freiburg - invasiv? AFZ-Der Wald 08(2016):25-28

Stijntje Janse-Ten Klooster SH, Thomas EJP, Sterck FJ (2007) Explaining interspecific differences in sapling growth and shade tolerance in temperate forests. J Ecol 95:1250-1260. https://doi.org/ 10.1111/j.1365-2745.2007.01299.x

Storch F, Dormann CF, Bauhus J (2018) Quantifying forest structural diversity based on large-scale inventory data: a new approach to support biodiversity monitoring. For Ecosyst 5:2-14. https://doi. org/10.1186/s40663-018-0151-1

Strubbe D, Shwartz A, Chiron F (2011) Concerns regarding the scientific evidence informing impact risk assessment and management recommendations for invasive birds. Biol Conserv 144:21122118. https://doi.org/10.1016/j.biocon.2011.05.001

Strubbe D, White R, Edelaar P, Rahbek C, Shwartz A (2019) Advancing impact assessments of non-native species: strategies for strengthening the evidence-base. NeoBiota. https://doi.org/10. 3897/neobiota.51.35940

Tomppo E, Gschwantner T, Lawrence M, McRoberts RE (2010) National forest inventories. Springer Science+Business Media B. V, Heidelberg, Dordrecht, London, New York

USDA (2000) NORTHERN RED OAK Quercus rubra L. Plant Guide

van Wilgen BW, Richardson DM (2014) Challenges and trade-offs in the management of invasive alien trees. Biol Invasions 16:721734. https://doi.org/10.1007/s10530-013-0615-8

Vanhellemont M, Verheyen K, De Keersmaeker L, Vandekerkhove K, Hermy M (2009) Does Prunus serotina act as an aggressive invader in areas with a low propagule pressure? Biol Invasions 11:1451. https://doi.org/10.1007/s10530-008-9353-8

Vansteenkiste D, De Boever L, Van Acker J (2005) Alternative processing solutions for red oak (Quercus rubra) from converted forests in Flanders, Belgium. In: Proceedings of the COST Action E44 conference on broad spectrum utilization of wood Universität für Bodenkultur Wien BOKU, Wien, Austria, p 13

Verheyen K, Vanhellemont M, Stock T, Hermy M (2007) Predicting patterns of invasion by black cherry (Prunus serotina Ehrh.) in Flanders (Belgium) and its impact on the forest understorey community. Divers Distrib 13:487-497. https://doi.org/10.1111/j. 1472-4642.2007.00334.x

Vítková M, Müllerová J, Sádlo J, Pergl J, Pyšek P (2017) Black locust (Robinia pseudoacacia) beloved and despised: A story of an invasive tree in Central Europe. For Ecol Manage 384:287-302. https://doi.org/10.1016/j.foreco.2016.10.057

Vor T (2005) Natural regeneration of Quercus rubra L. (Red Oak) in Germany. In: Nentwig W, Bacher S, Cock MJW, Dietz H, Gigon A, Wittenberg R (Eds) Biological invasions - from ecology to control, vol 6 NEOBIOTA, Berlin, Germany, pp 111-123

Vor T, Spellmann H, Bolte A, Ammer C (2015) Potenziale und Risiken eingeführter Baumarten Baumartenportaits mit naturschutzfachlicher Bewertung, vol 7. Universitätsverlag, Göttingen, Germany, Göttinger Forstwissenschaften

Vor T, Nehring S, Bolte A, Höltermann A (2016) Assessment of invasive tree species in nature conservation and forestry - contradictions and coherence. In: Krumm F, Vitcova L (eds) Introduced tree species in European forests: opportunities and challenges. European Forest Institute, Freiburg, Germany, pp 148-156

Wagner V et al (2017) Alien plant invasions in European woodlands. Divers Distrib 23:969-981. https://doi.org/10.1111/ddi.12592

Wohlgemuth T, Hafner J, Höltermann A, Moser B, Nehring S, Rigling A (2019) Impact of Douglas-fir on forests and open land habitats. In: Spiecker H, Lindner M, Schuler J (eds) Douglas-fir - an option for Europe. European Forest Institute, Joensuu, Finland, pp 57-62

Woziwoda B, Kopeć D, Witkowski J (2014) The negative impact of intentionally introduced Quercus rubra L. on a forest community. Acta Soc Bot Pol 83:39-49. https://doi.org/10.5586/asbp. 2013.035

Woziwoda B, Krzyżanowska A, Dyderski MK, Jagodziński AM, Stefańska-Krzaczek E (2018) Propagule pressure, presence of roads, and microsite variability influence dispersal of introduced Quercus rubra in temperate Pinus sylvestris forest. For Ecol Manage 428:35-45. https://doi.org/10.1016/j.foreco.2018.06.033

Publisher's Note Springer Nature remains neutral with regard to jurisdictional claims in published maps and institutional affiliations. 